\title{
Eesti varase tööliskirjanduse piirjooned ja tunnused
}

\author{
HEGELY KLAUS
}

Siinses artiklis on vaatluse all tööliskirjandus ning selle mõiste määratlemisega seotud probleemid. Kas on võimalik üheselt defineerida tööliskirjanduse ja -kirjaniku mõistet ning millel see põhineks? Artiklis antakse põgus ülevaade senistest uurimustest ja eri perioodide peamistest teoreetilistest seisukohtadest nii Eestis kui ka mujal. Samuti on lühidalt vaadeldud varasema eesti tööliskirjanduse omapärasid, seda peamiselt XX sajandi alguse teoste ning albumites „Edasi” (1905-1914/1915) ja „Mõtted” (1909, 1911) ilmunud tekstide põhjal.

Tööliskirjanduse uurimine on tänapäeva kirjandusteaduses esindatud tagasihoidlikult. Uuemate uurimuste nappus võib olla tingitud sellest, et eelmise sajandi tööliskirjanduse teoste kandvad teemad ei ole enam aktuaalsed. Tihti on tööliskirjanduse käsitlused pinnapealsed või põhinevad juba aegunud seisukohtadel ning nende kõrval on huvitavamadki uurimused jäänud suurema tähelepanuta. (Lennon, Nilsson 2017: 10-12) Mõiste klass, mis XX sajandi alguses ja keskpaigas oli vägagi päevakorral ja mida uuriti eeskätt (marksistlikust) majandusteooriast lähtuvalt, tõrjusid 1970.-1980. aastate kirjandusteaduses kõrvale niisugused mõisted nagu sugu, rass ja feminism (Clarke, Hubble 2018: 5); samuti olid sajandi lõpukümnendite võtmesõnadeks postmodernism ja punk (Hyttinen, Launis 2017: 85). Julian Markels (2003: 68) on juhtinud tähelepanu sellele, et soo ja etnilisuse uurimisviiside kõrval leidub viimase aja kirjandusteaduses võrdlemisi vähe teooriaid klassi käsitlemiseks.

\section{Tööliskirjanduse mõiste piiritlemisest}

Tööliste kirjutatud, töölisklassi jaoks loodud või tööliste eluolu kujutava kirjanduse kohta on kasutatud kaht eri mõistet: tööliskirjandus ja proletaarne kirjandus. Võib küsida, kumb neist on sisuliselt täpsem ning kas nende eristamine on üldse vajalik; kas kumbki pakub paremat võimalust sellelaadse kirjanduse mõistmiseks? Nõukogude perioodil kirjutatud „Leedu kirjanduse ajaloo” III köites („Lietuvių literatūros istorija III”, 1965) on kasutatud enamasti mõistet proletaarne kirjandus (ld proletarine literatūra) (Korsakas jt 1965: 53-176). Samal aastal välja antud „Soome kirjanduse ajaloos” („Suomen kirjallisuus V”, 1965) esineb aga samas tähenduses sõna tööliskirjandus (sm työväenkirjallisuus, työläiskirjallisuus) ${ }^{1}$ (Laitinen jt 1965: 128). Eesti

\footnotetext{
${ }^{1}$ Soome kirjanik ja kirjandusuurija Raoul Palmgren on eristanud mõisteid työväenkirjallisuus ja työläiskirjallisuus, mis mõlemad tähendavad tööliskirjandust: esimene hõlmab igasuguseid töölisklassile suunatud teoseid, teine aga täpsemalt töölisklassi poolt ja töölisklassi jaoks loodud ning töölisklassi olemust väljendavat kirjandust (Palmgren 1965: 222-223).
} 
kirjanduse kohta on mõlemat mõistet kasutatud sporaadiliselt. Venekeelset tööliskirjandust uuriv Katerina Clark (2017: 1) märgib, et mõistega proletaarne kirjandus viidati bolševistlikus kõnepruugis (eriti Nõukogude Venemaal, kuid ka varem) nii töölisklassi jaoks ja töölisklassi enda kirjutatud tekstidele kui ka konkreetselt Venemaa töölispartei (alates 1918. aastast kommunistlik partei) liikmete või pooldajate loodud kirjandusele. Rootsi kirjandusteadlane Magnus Nilsson (2017: 95) neil kahel mõistel aga vahet ei tee ning kasutab neid sünonüümidena. Seega erineb mõistete kasutamine kultuuriruumiti.

Eesti kirjanduses võiks mõistega tööliskirjandus viidata XIX sajandi lõpul ja XX sajandi esimesel poolel (enne nõukogude perioodi) loodud tekstidele ning mõiste proletaarne kirjandus võiks hõlmata nõukogude ajal loodud tekste, rõhutamaks, et viimastes on rohkem sotsialistliku realismi ${ }^{2}$ mõjusid: tegelaste seotus parteiga, positiivne kangelane, partei ja selle liikmete ülistamine (tööliskirjandust on sotsialistliku realismiga võrreldud veidi ka siinse artikli viimases peatükis). Eesti tööliskirjanduse ja -kunsti mõiste pärineb XX sajandi algusest. Tööliskunsti ja -kirjanduse termineid on kasutatud näiteks 1910. aasta Tallinna Teatajas (Tööliste hinge-elust 1910). Aasta hiljem, albumis „Mõtted II” on artiklis „Klassivahed ja „Noor-Eesti” kunst” loetletud ka tööliskunsti omapärad (Gailit 1911). Neid aastaid võibki pidada tööliskunsti ja -kirjanduse termini loomise ajaks. ${ }^{3}$ Varasema eesti tööliskirjanduse kandvateks ideedeks olid vaesemate klasside eluolu ja kannatuste kirjeldamine, kapitalismi ja industrialiseerimise kriitika, klassivõitluse tähtsustamine ja revolutsiooniline meeleolu.

Järgnevalt esitan tööliskirjanduse määratlused, millest lähtutakse rohkem või vähem ka tänapäeva kirjandusteaduses, ning nende kriitika. Raoul Palmgren (1965: 222-223) on defineerinud tööliskirjandust niisuguste tunnuste kaudu: 1) see peegeldab proletariaadi pärimust ja kogemusi; 2) see väljendab proletariaadi maailmavaadet; 3) see kajastab töölistemaatikat; 4) sellel on proletaarne mõjusfäär; 5) sellel on teatud stilistilised omapärad: jõuline ja karm väljenduslaad, iseloomulik keelekasutus, suund naturaalsuse ja vaba vormi poole. Palmgreni alates 1935. aastast arendatud definitsioon on kasutusel olnud pikalt - sellele toetus ka Kai Laitinen „Soome kirjanduse ajaloos” (1991). Kirjandusuurijad Elsi Hyttinen ja Kati Launis (2017: 82) märgivad, et kirjaniku elutingimuste pidamine (töölis)kirjanduses esinevate esteetiliste omapärade ajendiks, nagu Palmgreni määratluses, langeb kokku marksistliku maailmavaatega, mille kohaselt kultuur kui pealisehitis kajastab töö ja töötamise põhjapanevat osa ühiskonnas. Hans Pöögelmanni (1933: 7) sõnul hindab marksistlik arvustus kunsti „klassivõitluse, proletaarse revolutsiooni huvide seisukohalt”, lähtuvalt kunstiteoste „sisust, ideoloogilisest vaatekohast ja väärtusest”. Seega peab marksistlik kriitika kunstiteoste loomise ajendiks autorit ümbritsevat maailma.

\footnotetext{
${ }^{2}$ Nõukogude Liidus XX sajandi alguse tööliskirjandusest välja kasvanud sotsialistlik realism oli 1929. aastast ainus lubatud loominguline meetod. Selles puudusid varasemale tööliskirjandusele omased mässumeelsus ja revolutsioonilisus, kuid endiselt olid esindatud kapitalismi kriitika, tööliste õigused ja klassivõitlus.

${ }^{3}$ Võrdluseks: Soome ajakirjanduses arutati tööliskirjanduse mõiste üle esmakordselt 1904. aastal töölislehe Työmies (1895-1918) veergudel (Hyttinen, Launis 2017: 72).
} 
Rootsi tööliskirjanduse uurija Lars Furulandi (viidatud Nilsson 2017: 95 järgi) arvates on tööliskirjandus tööliste poolt, tööliste kohta ja nende jaoks kirjutatud teoste ristumiskoht, mis lisaks sisaldab ideoloogilist komponenti. Sarnaselt Furulandiga rõhutab Clark (2017: 1) vene tööliskirjandusest rääkides ideoloogiat: marksistlik-leninistliku vaate järgi oli „ideaalne proletaarlane” nii töölisklassi päritolu kui ka kommunistliku partei liige, nii oli ka enamik XX sajandi alguse tööliskirjanduse teoste peategelasi töölisklassist ja rohkemal või vähemal määral parteiga seotud. Clark toob näiteks Maksim Gorki „Ema” (1906, e k 1934), kus vabrikutöölisest noormees saab tänu revolutsionääridest kaaslastele ligipääsu poliitilisele kirjandusele ning kujundab nende teoste põhjal ka oma maailmavaate (Clark 2017: 3-4). Sellest romaanist sai hiljem vene sotsialistliku realismi üks mudelteoseid, just poliitilise hariduse propageerimise ja positiivse kangelase olemasolu tõttu (Clark 2017: 4). Clark (2017: 9) lisab, et pärast Nõukogude Liidu loomist tõusid teravalt esile kaks leeri: ühed uskusid, et proletaarne kirjandus peab olema tööliste endi kirjutatud ja nende jaoks, teised leidsid, et see peab olema kommunistliku partei liikmete loodud või parteist kirjutatud. Soome tööliskirjanduse määratlusega võrreldes on niisiis rootsi ja vene kirjandusteaduses enam rõhutatud poliitilisi aspekte.

Tööliskirjanduse mõiste üle on nii Eestis kui ka mujal vaieldud rohkem kui sada aastat, kuid tulenevalt nii kultuuriruumide erinevustest kui ka eri perioodidele iseloomulikest tööliskirjanduse variantidest pole senini ühtse, üldiselt aktsepteeritava definitsioonini jõutud (Hyttinen, Launis 2017: 86). Leitud pole ka ühtset eesti tööliskirjanduse määratlust. Ometi on tööliskirjandusel paljude riikide kirjandusloos omapärane roll, ehkki positsioonid võivad olla muutunud. Näiteks on Nilsson ja John Lennon (2016: 40) nentinud, et Ameerikas on XIX sajandi lõpu ja XX sajandi alguse tööliskirjandus ja selle uurimine oma tähtsuse minetanud, Rootsis aga peetakse seda ka tänapäeval rahvuskirjanduse oluliseks osaks. Selle põhjusteks on Nilssoni ja Lennoni arvates külm sõda ja sellega kaasnenud pikaajaline politiline propaganda ${ }^{4}$ Ameerikas ning töölisklassi kirjanduse esteetiline ümberhindamine Rootsis, mistõttu on rootsi kirjandusteaduses tööliskirjandust tihti käsitletud kui lihtsalt kirjandust (Nilsson, Lennon 2016: 40). Nii ongi olnud keerukas leida ühtset tööliskirjanduse definitsiooni.

Samuti ei leidu kindlat tööliskirjaniku määratlust. Palmgreni (1965: 222-223) järgi on õige tööliskirjanduse kirjutanud töölised ise ja see kannab nende maailmavaadet. Seejuures on harilikult liigitatud töölisteks vaid neid, kes teenivad elatist raske füüsilise tööga suurtööstuses või mõisates. Inglise kirjanduse uurija Gustav $\mathrm{H}$. Klaus (1985: 9) aga väidab, et tööliste endi kirjutatud tööliskirjandus oli harv nähtus ning suurema osa teoseid kirjutasid hoopis kirjanikud väljastpoolt töölisklassi. Eestiski polnud laiemalt tuntud tööliskirjanikud enamasti tavalised töölised, ehkki nad olid proovinud ameteid vabrikus või mõisas: näiteks Hans Pöögelmann ja Jaan Anvelt olid seotud poliitikaga, Juhan Lilienbach toimetas mitut väljaannet ja oli kirjastuse omanik, Otto Münther ja Villem Buk omandasid õpetajakutse, Vassili

\footnotetext{
${ }^{4}$ Külma sõja propaganda all on mõeldud kommunistlike vaadete negatiivset ja kriitilist esitamist, mille tulemusel Joseph McCarthy loodud külma sõja komiteed jälgisid hoolega ülikoolides levivaid mõttevoole ja diskrimineerisid eriti nimetatud voolude uurijaid (Nilsson, Lennon 2016: 48).
} 
Mölder oli rändraamatukaupmees ja ajakirja Hääl toimetaja. Pöögelmann, Anvelt ja Münther omandasid ka kõrghariduse. Palmgreni väidet toetab aga venekeelses kultuuriruumis XX sajandi alguses levinud arusaam, et venekeelne tööliskirjandus peab pärinema ainuüksi töölisklassi kirjanikelt ning enne 1917. aasta revolutsiooni oligi see suuremas osas just lihttööliste kirjutatud (Clark 2017: 2). Selline arusaam võis võrsuda tollase venekeelse tööliskirjanduse ühe tuntuma autori Maksim Gorki, laiemalt kogu Capri kooli ${ }^{5}$ liikmeskonna jahedast suhtumisest modernistlikesse ja dekadentlikesse kirjanikesse, kes proovisid kätt tööliskirjandusega, aga Gorki sõnul ei suutnud nad tabada tööliste maailmavaadet (Clark 2017: 6-7).

Soome XX sajandi alguse kirjaniku Kössi Kaatra arvates on tööliskirjanik masside poeet, tema looming peab peegeldama kogu töölisklassi tundeid, mitte lähtuma individuaalsetest elamustest (vt Launis 2015). See tähelepanek on asjakohane ka eesti tööliskirjanike loomingust rääkides: „meie” vaatenurk tuleb selgelt esile just töölisluules. Eestis on peale eelmainitud autorite nimetatud veel selliseid tööliskirjanikke nagu Elise Tenter, Gustav Tikerpuu, Jaan Kreek ja Johan Wilhelm Kruberg (varjunimega J. Vermontius) (vt Pöögelmann 1933; Sikemäe, Lepik 1951). Tööliskirjaniku staatuse on neile andnud avalikkus lähtuvalt nende selgetest poliitilistest seisukohtadest (kapitalistliku ühiskonna kukutamise ja ühes sellega töölisklassi elujärje parandamise idee), eneseteadvusest ning loomingu peateemadest (klassivõitlus, tööliste eluolu ja töötingimused, sotsialismi ja marksismi ideed, kapitalismi kriitika jms). Nendest kolmest aspektist võikski tööliskirjaniku määratlemisel lähtuda. See jätab mänguruumi ka Palmgreni rõhutatud tööliskirjaniku päritolu tingimusele, millega aga siinse artikli autor ei nõustu.

Nagu sissejuhatuses osutatud, on paljud tööliskirjanduse määratlused vananenud, sest need toetuvad XX sajandil levinud marksistlikele vaadetele. Tänapäeval tööliskirjandust piiritledes ja klassiteooriaid kasutades tuleks aegunud definitsioonid ümber hinnata. Lihtsustatud seletus, et tööliskirjandus on tööliste poolt ja tööliste jaoks loodud ning tööliste maailma kujutav kirjandus, on problemaatiline ega pea paika. Võibki öelda, et tööliskirjanduse mõiste on justkui paljude erinevate määratluste kogum, mida iseloomustab definitsioonide pidev kummutamine. Selles artiklis on eesti tööliskirjandusest rääkides lähtutud mitte niivõrd konkreetsest definitsioonist, kuivõrd pigem tunnusjoontest, millest olulisemad on esitatud artikli viimases osas.

\section{Tööliskirjanduse senisest uurimisest}

Tööliskirjanduse uurimisel lähtuti kuni eelmise sajandi keskpaigani enamjaolt marksistlikust või rahvuslikust ehk geograafiliselt piiritletud raamistikust. Sarnaselt soome ja rootsi uurimustega on ka Eestis vaadeldud tööliskirjandust peamiselt rahvuslikust aspektist, nähes sellise loomingu ajendina siinseid XIX sajandi lõpu ja XX

\footnotetext{
${ }^{5}$ Maksim Gorki, Aleksander Bogdanov, Anatoli Lunatšarski ja teised XX sajandi alguse aktiivsemad Venemaa töölispartei liikmed juhtisid aastatel 1909-1910 tööliste õpetamiseks ja nende silmaringi laiendamiseks loodud kooli Capri saarel (Clark 2017: 5).
} 
sajandi alguse poliitilise arengu tagajärgi - näiteks kohaliku töölis- ja talupojaklassi vastuolu mõisnikega ning rahulolematust tsaarivalitsusega (Karjahärm, Pullat 1975: 33; Karjahärm 2013: 146). Lennon ja Nilsson (2017: 11) rõhutavad aga, et tänapäevase tööliskirjanduse uurimise jaoks on need teoreetilised seisukohad vananenud ning töölisklassi analüüsimiseks ilukirjanduse põhjal on tarvis uusi vahendeid. Aegunud on needki põhjalikud tööliskirjanduse käsitlused, mis ilmusid alles XX sajandi lõpus. ${ }^{6}$

Eelmise kümnendi poliitiliste olude, ${ }^{7}$ samuti 2008. aastal alguse saanud majanduskriisi tõttu on taas hakatud rohkem tähelepanu pöörama ühiskonnaklassile (Russo, Linkon 2005: 3; Clarke, Hubble 2018: 5), seda ka kirjandusteaduses, ehkki Eestis vähem kui näiteks Rootsis, Inglismaal, Soomes või Ameerikas. Klassi ja tööliskirjanduse uurijad John Lennon, Nick Hubble, Magnus Nilsson, Ben Clarke, Katerina Clark jt on varasematest meetoditest kaugenedes algatanud uusi arutlusi tööliskirjanduse üle ning kasutanud mõiste määratlemisel ja nähtuse uurimisel feminismi, soo ja rassi, postkolonialismi, seksuaalsete ja etniliste identiteetide jm teooriaid, mis varasematest tööliskirjanduse käsitlustest puudusid. Praegusi tööliskirjanduse uurimusi iseloomustab avar interdistsiplinaarne vaatenurk ning rahvuslikest piiritlustest eemaldumine, mille silmatorkav näide on Sonali Perera (2014) monograafia globaliseerumisaja tööliskirjandusest. Kuidas on aga Eestis tööliskirjandust uuritud?

XX sajandi alguses olid eesti tööliskirjanduse käsitlused osalt ettekirjutava iseloomuga: jagati juhtnööre, milline peaks olema n-ö õige tööliskirjanduse teos. Uurivate või analüüsivate käsitluste nappust põhjendab see, et siinne tööliskirjandus oli sajandivahetusel alles kujunemisfaasis ning mõiste olemus polnud veel selge. Julgemaid juhtnööre jagavad artiklid ilmusid XX sajandi alguses välja antud töölisalbumites, mis olid Eestis esimesed omalaadsed tööliskirjanduse kogumikud. Albumis „Mõtted I” (1909) kirjutab J. Elbe, et tööliste kirjanduses peab kindlasti olema realistlik aines, mis eristab seda kodanlikust kirjandusest, kus pandi rõhku „ilusale pildile" (1909: 121). Seega peab tööliskirjandus vastanduma kodanlikule kirjandusele. Näiteks võrdleb Hans Pöögelmann (1907) kodanlikku ja tööliste kunsti ning toob kummagi kirjanduslaadi erinevused esile ema tunnete kirjeldamise näitel: rikkal lapsevanemal on ilus ja armas oma last mööda liivateed kärutada, kuid vabrikutööline mõtleb kibedalt ja valusalt, et „tema tibuke peab... oh Jumal, selle kannatused üsna kasvavad". Realistliku ainese kujutamise kohta lisab Otto Münther (1914/1915: 6) Tšehhovile toetudes: „Meie [tööliskirjanikud] kujutame elu, nagu ta on, ja kaugemale mitte ptrru, mitte nõõ..." Münther (1914/1915: 3, 8) kritiseerib ka kirjanikke, kellel puudub „sotsialpolitikaline nägu” ning kes „ei võta oma tööde aluseks laiemat elu, selle võitlust, ega ta püüdmisi valguse poole”. XX sajandi alguse töölisalbumi-

\footnotetext{
${ }^{6}$ Nt Walter Rideouti „The Radical Novel in the United States, 1900-1954: Some Interrelations of Literature and Society” (1992), Janet Zandy „Calling Home: Working-Class Women's Writing” (1993), Pamela Foxi „Class Fictions: Shame and Resistance in the British Working-Class Novel 1890-1945” (1994), Ian Haywoodi „Working-Class Fiction: From Chartism to Trainspotting” (1997).

${ }^{7}$ Näiteks Donald Trumpi saamine Ameerika presidendiks, Theresa May „sinikraeline konservatism" ning poolehoid töölisklassile, samuti Eesti Konservatiivse Rahvaerakonna kui populistliku partei juhtiv positsioon.
} 
tes ilmunud artiklitest tuleb seega esile, et tööliskirjanduse määravateks tunnusteks peeti realistlikku elu kujutamist, sotsiaalpoliitilist seisukohavõttu, võitluslikkust ja parema elu poole püüdlemist.

Tööliskirjandust iseloomustavad või uurivad artiklid, mis püüdsid vastata küsimusele „milline on eesti tööliskirjandus?”, olid enamasti siiski üsna pealiskaudsed ning aspektid, mida rõhutati ja mille üle arutleti, ei vastanud tollase eesti kirjanduse tegelikele omadustele. Pigem iseloomustasid mainitud omapärad välistööliskirjanike, näiteks Nekrassovi, Gorki jt loomingut. August Gailit (1911: 92) kirjutab albumis „Mõtted II”: tööliskirjanduses ja -kunstis „lauldakse kiitust võitlejatele, punutakse aupärg „meeletutele”, kes langesid tormijooksus vaenlase vastu, ${ }^{8}$ seal sütitatakse sõjatuld, puhutakse vaimustuse leekisid, seal on evangeelium „vaevatutele ja koormatutele'”. Need omadused on sajandialguse eesti töölisalbumite luuletustes küll esindatud, kuid märksa tagasihoidlikumalt ja lihtsakoelisemalt, kui Gailit mõista annab. Näiteks 1905. aasta jõuludeks ilmunud albumis „Edasi” leidub Jaan Kreegi (1905) luuletus, kus näljast nõrkenud tööline nutab haige ema voodi ees ning „aupärja punumise” asemel kajastuvad revolutsioonisündmused vaid aimamisi: „Sajad pildid, juhtumised, / kõik nii värskelt elavalt...” Samas albumis ilmunud Lilienbachi (1905) luuletuse „Üksainus soov” lõpurida „Ma tahan ainult elada” kätkeb küll tööliste eluiha, aga seda siiski malbemalt, kui lubab Gailiti üldistus. Gailiti artikkel on aga hea näide sellest, kuidas tollase eesti tööliskirjanduse käsitlustes väljendati julgeid ja teravaid mõtteid: „töölisklass on ainus, kes kunsti ja kultuuri päästab" (Gailit 1911: 111). Niisuguste sõnavõttude eest pälvisid autorid ka kriitikat. Näiteks töölisalbumisse „Mõtted II” (1911), kus muu hulgas on Gailiti artikkel „Klassivahed ja „Noor-Eesti” kunst”, suhtus Bernhard Linde (1911) äärmiselt negatiivselt, kaitstes sel viisil nooreestlasi.

Vabariigiaegsel perioodil avaldati tööliskirjanduse uurimusi või tööliskirjanduse tunnustele keskenduvaid käsitlusi vähe. Oma osa on selles kindlasti asjaolul, et pärast enamlike organisatsioonide tegevuse keelustamist 1918. aastal muutusid mitmed tööliste häälekandjad (Uus Ilm, Kiir, Edasi, Töörahva Hääl, Tööline jm) n-ö põrandaalusteks (Kuuli 1999: 10-19). Osa tööliskirjanduse loojaid ja uurijaid suundus hoopis Nõukogude Liitu ja avaldas oma tekste Leningradis. Siiski on käesolevas artiklis käsitletud neidki eesti tööliskirjanduse ja selle uurimistraditsiooni raames: teoseid kirjutati siiski eesti keeles ja siinsele lugejale, samuti käsitleti Leningradis ilmunud ülevaateis eesti kirjandust.

Sajandi esimestel kümnenditel aeg-ajalt ilmunud emotsionaalsed ja revolutsioonimeelsed artiklid (Münther, Gailit, Pöögelmann) hakkasid aga tasahilju asenduma pikemaid poliitilisi seletusi, põhjendusi ja analüüsi sisaldavate tekstidega. Näiteks Peeter Meiseli (1932) artiklis „Viis aastat võitlust eesti proletaarse kirjanduse eest” torkab silma, et ehkki endiselt tähtsustati tööliskirjanduses ja ka selle retseptsioonis realistlikku vaatenurka, teravnes poliitiline toon koos sotsialismi, marksismi ja kom-

\footnotetext{
${ }^{8}$ Tõenäoliselt on siin silmas peetud 1905. aastal Peterburis aset leidnud Verist pühapäeva, kus meeleavaldajate pihta avati tuli, või sama aasta 29. oktoobril (vkj 16. oktoobril) Tallinnas Uuel turul toimunud meeleavaldust, kus sõjaväeüksus tulistas rahvahulka, tappes 94 ja haavates üle 100 inimese.
} 
munismi ideoloogiate väljendamisega. Teoste käsitlustes õhutati tööliskirjanikke panema rohkem rõhku sisulisele poolele. Meisel (1932: 8) märgib, et tööliskirjanduse teoses „tuleb jätta peaaegu puutumata stiil, kompositsioon, üldse vormiküsimused, ehk puudutada neid õige pealiskaudselt, ainult niivõrd, kuivõrd see on hädatarvilik ideelise ja kirjandus-poliitilise suuna jälgimisel”. Hans Pöögelmann (1933: 5-9) tähtsustab marksistlikust ideoloogiast lähtuvat kunsti ja kirjanduse analüüsi, vastandades seda „valgele eesti ajakirjandusele” ja „Kampmannide, Ridalate, Tuglaste j.t.” kirjandusloolistele töödele.

Erinevalt soome, rootsi, briti või ameerika tööliskirjanduse käsitlustest on siinset uurimistraditsiooni mõjutanud nõukogude ideoloogia, mis vaatles tööliskirjandust kitsast, poliitiliselt aktsepteeritavast vaatenurgast. 1951. aastal ilmunud tööliskirjanduse antoloogia „Eesti proletaarne kirjandus” järelsõnas on antud lühike ülevaade eesti proletaarse kirjanduse ajaloost ja seda kirjandust ka pisut iseloomustatud, näiteks marksistlikelt alustelt, võrdluses kriitilise realismiga ja dekadentsile vastanduvalt (Sikemäe, Lepik 1951: 270-310). Selles kokkuvõttes on rõhutatud eesti tööliskirjanduse seost vene töölisklassi ja revolutsionääride tegevusega. Nõukogude ajal kasvas töölis-/proletaarset kirjandust käsitlevate artiklite hulk. Näiteks ilmusid Keeles ja Kirjanduses Nigol Andreseni (1959) ja Heino Puhveli (vt Kalda 1958) arvustused tööliskirjaniku Eessaare Aadu (Jaan Anvelti) loomingust. Johan Depman (1961) arvustas töölisluuletaja Juhan Lilienbachi loomingut, Meelik Kahu (1967) vaatles eesti töölisajakirjandust, Eduard Ertis (1967) andis ülevaate Eesti Proletaarsete Kirjanikkude Assotsiatsioonist Leningradis.

Tänapäeva eesti kirjandusteaduses on tööliskirjanduse uurimine soikunud. Ühelt poolt võib selle põhjusena näha sihilikku hoidumist nõukogude ajal propageeritud kirjandusest, mille hulka kuulusid ka töölistemaatikat ja sotsialistlik-marksistlikke ideid kandvad teosed. Teisalt ei ole XX sajandi tööliskirjanduse mõningad probleemteemad, näiteks töölisklassi kohutavad elu- ja töötingimused ning klassivõitlus, enam aktuaalsed, seda just arenenud riikides, mis on tinginud ka vähese uurijahuvi. XIX ja XX sajandi vahetuse ühiskonnaprobleeme ja töölistemaatika avaldumist näiteks Eduard Vilde loomingus ning sotsialismi kirjanduses on kaudselt puudutanud Cornelius Hasselblatt „Eesti kirjanduse ajaloos” (2016: 277-303, 351-354). Tööliskirjanduse ja revolutsiooni suhteid on vaadelnud Aare Pilv artiklis „Eesti varamarksistlikust koidust punapagulaste tragöödiani” (2015). Erinevatel perioodidel on eesti tööliskirjandust määratletud ja uuritud lähtuvalt parajasti valitsevatest tavadest: XX sajandi alguse ettekirjutav laad või nõukogude perioodile omased ideoloogilised lisandused ilmselgelt puuduvad näiteks eeltoodud Hasselblatti ja Pilve käsitlustest.

\section{Eesti varase tööliskirjanduse omapärad}

Tööliskirjanduse kandvad ideed hakkasid kujunema juba Prantsuse revolutsiooni ajal. Ühena esimestest kasutas tööliskirjanduse elemente, nagu klassivastuolud ja industriaalühiskonna pahupool, saksa luuletaja Georg Weerth (1822-1856). 1870. aastatel edendasid Prantsusmaal tööliskirjandust Eugène Edine Pottier - kes kirjutas 
ka rahvusvaheliselt tuntuks saanud töölislaulu „Internatsionaal” („L'Internationale”, 1871, e k 1905) -, Louise Michel ja teised Pariisi radikaalsotsialistlikud poeedid. (Puhvel 1969: 577) Inspiratsiooni saadi marksismist, mis keskendus suures osas kapitalismi ja töölisklassi ekspluateerimise kriitikale (Jennings 2003: 9). 1895. aasta, mil Lenin asutas Venemaal Töölisklassi Vabadusvõitluse Liidu ning Soomes pandi alus esimesele töölisajakirjale Työmies, märgib mõlemas riigis tööliskirjanduse algust (Sabolev 2017: 126; Hyttinen, Launis 2017: 79).

XIX sajandi lõpu ja XX sajandi alguse Eestis ringles mitmekesist kirjavara: peale (balti)saksa autorite teoste ja venekeelse kirjanduse, mida loeti palju 1880. aastatel alguse saanud venestamise tulemusena, arenes ka eestlaste enda looming (Hasselblatt 2016: 239-247). Artur Adson (1948: 73) mainib oma mälestustes „väljasureva aadli literatuuri, demokraatliku intelligentsi kirjandust, kodanluse, revolutsiooniliste tööliste ja proletariaarlaste kirjandust ja lõpuks sümbolismi”. Mitmekesistus teemaring, ent sagedasteks märksõnadeks kujunesid just töölisklass, klassivastuolud ja linnastumine. Sajandivahetusel hoogustus realistlik kirjandus, mida Hasselblatt (2016: 277) on põhjendanud nõnda: „Valitses üldine nõudlus tekstide järele, mis tegeleksid rohkem tolleaegse reaalsusega ja inimeste aktuaalsete probleemidega, annaksid teada inimeste muredest ja vajadustest siin ja praegu [---]" Tollane realistlik eesti kirjandus oli tihedas seoses saksa biidermeierliku kirjandusega, mis oli oma laadilt lihtne, argine ja moraliseeriv (Jänes jt 1938: 21), ning romaanile peeti kohustuslikuks kujutada „oma aja lapsi” ja „tegelikkusele vastavat esitust” (Annus jt 2001: 120). Samuti mõjutasid sajandivahetuse kirjandust sotsialismiideed ja sotsiaalsete probleemide kajastamine päevapoliitilistes väljaannetes (vt Hasselblatt 2016: 352-354; Annus jt 2001: 119).

Esimesi tööliskirjanduslikke kirjutisi võib leida juba XIX sajandi lõpu ajakirjandusest (Linda, Postimees, Sakala lisa, Rahva Lõbuleht jm) (Jaakson 1955), ka töölisliikumine sai Eestis alguse 1890. aastate keskpaigas, mil „tööliskond hakkas end tunnetama revolutsioonilise klassina" (Tuglas 1947: 6). Varaseimad tekstid, mis sisaldavad töölisliikumise ideid (klassivastuolud, tööliste vilets eluolu ja kehvad töötingimused, ülekohus ülemate poolt jm), on kahtlemata tähtsad, ent eesti tööliskirjanduse alguspunktiks on siiski peetud 1905. aastat (nt Tuglas 1947: 6; Puhvel 1969: 57), mil ilmus esimene omalaadne, töölisalbumite traditsiooni algatanud töölisalbum „Edasi”, kus olid töölisklassi probleemid ja seisukohad juba selgelt välja joonistunud. Eesti tööliskirjanduse kõrgaeg jäi kahe revolutsiooni - 1905. aasta ja 1917. aasta - vahele. ${ }^{9}$ Ainuüksi töölisalbumites kujutatakse proletaarset revolutsiooni, eri ühiskonnakihtide ja rahvuste teravat vastandamist, tööliste viletsat elu- ja tööolu; samuti esineb vabaduse, orjuse ja surma motiive (vt nt Klaus 2019: 53-62).

\footnotetext{
${ }^{9}$ Tööliskirjandust avaldati ajakirjades ja pilkelehtedes. Samuti ilmusid tööliskirjanduse albumid „Edasi” (I-XI, 1905-1917), „Mõtted” (I-II, 1909-1911), „Ääsi tules” (I-II, 1908-1910). Avaldati luulekogusid, nt Vassili Möldri „Sõnajalad” (1911), Hans Pöögelmanni „Jämedad jooned” (1910) ja Juhan Lilienbachi „Ommikulaulud” (1909), samuti novellikogusid, nt Otto Müntheri „Sulejoonistused” (1906). Ilmus ka rohkelt tõlkekirjandust, nt Upton Sinclairi „Rahavahetajad” (,The Moneychangers”, 1908, e k 1909) ja „Metropol” („The Metropolis”, 1908, e k 1912), Émile Zola „Numea vang” („Le ventre de Paris”, 1900, e k 1905) ja „Söekaevurid” („Germinal”, 1885, e k 1908 pealkirjaga „Söekaevajad”) jt.
} 
Eesti tööliskirjandust iseloomustab pilkav või ironiseeriv suhtumine töölisliikumise vastastesse. Näiteks pilkab Juhan Lilienbachi (1910a) luuletus „Kunstnikule” ilmselt nooreestlaste esteetilist programmi: „Moodsalt, kunstiliselt püiab / kirjutada ta; / lihtsalt mõtteid avaldada - / seda katsun ma. // Nõndaviisi põhjalikult / lahku lähevad / meie kirjad, meie püüded, / meie lugejad." Eesti sajandialguse töölisajakirjandusse kuulus mitu revolutsioonilist huumori- ja satiirilehte. Lilienbachi välja antud pilkelehtedes ja -ajakirjades (Tiiu Tasane, ${ }^{10}$ 1906; Ajakohane Naljaleht, 1906; Edu, 1906; Pilkeleht, 1906; Reinuvader, 1906; Nooled, 1906; Kolerakülvaja, 1907; Vali Tali, 1908; Tapper, 1917-1918) on esitatud kriitiliselt neid, kelle seisukohad töölisklassi omadest erinesid: erakondi, poliitikuid ja muid avaliku elu tegelasi; samuti on äratuntavalt kujutatud konkreetseid vabrikuid, linnu, ehitisi jms. Lilienbachi Lendlehe neljas number lisapealkirjaga „Walinali” pilkab aga tervenisti Eesti Rahvameelset Eduerakonda ja Jaan Tõnissoni.

Valdavalt on tööliskirjanduse ainealaks peetud vabrikuid ja linnamaastikke. Eesti ilukirjanduses aga on „proletaarne linn, sotsialistlik tehas ja vabrik” pigem tähelepanu alt välja jäänud (Meisel 1932: 26). Ainus silmapaistev vabrikuolusid kujutav luuletus sajandi algusest on Kosto Vibulase "Vabrikus” töölisalbumis „Mõtted I” (1909). Jaan Kärneri luulekogus „Aja laulud” (1921: 45-53) leidub viis töölise vaatepunkti esitavat luuletust, kus kujutatavaks ruumiks on samuti vabrik ning mis on mässumeelsed ja toovad esile meie-nende vastanduse (nt vabrikandid kui timukad luuletuses „Kõigile timukaile”). Kärnerit ei saa küll pidada töölisluuletajaks, ometi kannavad viidatud luuletused tugevalt tööliskirjanduse vaimu, maalides mustvalge pildi lõppematust vabrikutes rügamisest, ülekohtust ning töölistes pulbitsevast klassivihast: „Tööline, nagu mesilane oma kehast pigistab / mett, kärgi, oma elu ära annab, välja higistab. / Ent kellel mahti selle pääle mõeldes jännata? / Aeg sarnane, et peremees vaid joo!" (Kärner 1921: 46)

Sagedamini aga on linna ja vabrikute asemel kujutatud hierarhilist külaühiskonda, iseäranis talupoegade ja mõisnike vastasseisu, samuti sotsialismi vaimus protsesside ümberkorraldamist maal, ning väljendatud tsaarivalitsusega rahulolematust (Meisel 1932: 22, 26; Laul 1955: 3). Ka töölisliikumises domineerivaid ideid ja arusaamu, näiteks et kapitalism esindab dehumaniseerunud tööstust ja vabaduse puudumist ning tootmisvahendite eraomandusega kaasneb töölis- ja talupojaklassi ekspluateerimine, mõistsid ja kujutasid eesti tööliskirjanikud tihti külaolustikus levinud probleemsituatsioonide kaudu. Lilienbachi luuletuses „Lambatall” (1910b) annavad mõisnikest või vabrikuomanikest „karjased” metafoorselt „mööda keret” eestlastest talupoegadele või töölistele ehk „lambatalledele” ja mõisavalitsejat või vabrikutöölise ülemust ehk „karjakoera” tuleb karta teravate hammaste tõttu. Selles luuletuses tuleb klassivastuolude kriitika ning hierarhilise ühiskonna paljastamine esile just mõisniku ja talupoja vahekorra kujutamise kaudu. Eesti tööliskirjanduses põimuvad seega ühelt poolt töölisliikumise ideed, mida levitasid linna välja rännanud töölised või seal elanud üliõpilased, ja teiselt poolt tavapärasest laiem ainestik:

\footnotetext{
${ }^{10}$ Pealkiri on tõenäoliselt võrsunud XVIII sajandi sentimentaalsest armastuslaulust „Tio tassane
} ja helde" (Suits, Lepik 1932: 153-154). 
põllumajanduslik maailmavaade, mida kandsid maal elavad või maalt linnadesse asunud talupojad.

Eesti tööliskirjandust iseloomustab ka töölise elu võrdlemine orja omaga. Orjuse motiivi kasutamine on mitmetähenduslik: sellega võidi viidata tööliste ebainimlikule koormusele vabrikutes või suhtele tööandjaga, ent mõiste ori kätkeb ka valusat mälestust pärisorjuse ajast. Näiteks kirjutas Kosto Vibulane (1910a): „Ma elan orjaahelates, / mu ümber pime, viletsus”, milles „orja-ahelad” võib osutada nii möödunud aegade elukorraldusele kui ka tööandjale ja töökohale. Orjuse motiiviga käivad tihti kaasas baltisaksa mõisnike ja kohalike eestlaste mustvalged määratlused, kus esimesi tähistatakse sõnaga nemad ning keda kujutatakse alati negatiivsest vaatenurgast, teiste kohta kasutatakse meievormi ning nende mõtte- ja teguviise püütakse õigustada. Eesti töölisluulele on omane ka rahvuste terav vastandamine. Näiteks Vibulase (1910b) luuletuses „Lahkumine” on kirjas: „Talle saivad siidipüksid, / mulle tehti takused, - / sellest ajast saadik juba / meie meeled lahkusid." Siin tuleb esile siidipükse kandva kõrgklassi ja takuseid pükse kandva alama klassi võrdlus, samuti on rõhutatud seisustevahelisi erimeelsusi.

Eesti tööliskirjanduses võib märgata omapärast vormi ja stiili ning iseloomulike motiivide ja lausekujundite kasutamist. Heino Puhvel (1969: 57-58) on täheldanud, et eesti töölisluulet iseloomustavad publitsistlik otseütlemine, teravad ja romantilised metafoorid, lähedus rahvaluulele jm. Peale selle on luuletused enamasti lühikesed ja neile on omane lausekujundite (korduste, ebatavalise sõnajärje jt) vähesus, kindel silbilis-rõhuline värsisüsteem ja meievorm, samuti rahvaluule ja -pärimuse elementide kasutamine (Klaus 2019: 63-68). Võib oletada, et korrapärases rütmis luuletused võisid lugejaile meenutada marsisammu ja ülestõusude revolutsioonilisi ühislaulmisi ning seeläbi mõjuda töölistele köitvalt. Rahvaluuleelemente võidi tööliskirjanduses kasutada seetõttu, et XIX sajandi lõpu ja XX sajandi alguse töölis- ja talupojaklassi eneseteadvus tugines suuresti rahvapärimusele. Lausekujundite vähest esinemist ja otseütlemist eesti tööliskirjanduses võib põhjendada sellega, et prioriteet oli konkreetsete olukordade esitamine, tegutsemissuuna andmine, võitlusvaimu tõstmine, töölisliikumise ideede seletamine, probleemide kujutamine ja nendele lahenduste pakkumine, mitte niivõrd laiahaardeliste narratiivide või lüüriliste sisevaatluste loomine. Samuti võiks Jacques Rancière'ile (2012: 76) toetudes põhjendada tööliskirjanduse konkreetsust, lihtsust ja argisust sellega, et poeetilise kujundlikkuse haaramiseks vajalik mõttetöö pärast pikka ja füüsiliselt rasket tööpäeva oli lihttööliste ehk peamise lugejaskonna jaoks vaevanõudev.

Eesti tööliskirjanduse iseloomustamisel võiks abi olla selle kõrvutamisest teiste XIX sajandi lõpus ja XX sajandi alguses levinud realistlike kirjandusvooludega. Ühiskonnakriitilistes XIX sajandi lõpu või XX sajandi alguse teostes on vaadeldud ühest küljest kõrgklassi elu, mida on esitatud võltsi, küünilise ja jultununa, ning teisalt madalamaid ühiskonnakihte, nende viletsust, osutades ebavõrdsusele. Sama on tehtud ka tööliskirjanduses, keskendudes sealjuures rohkem vaesemate klasside eluolule. Eripärane on aga tööliskirjanduse tähelepanu sotsialistlik-marksistlikust maailmavaatest tõukunud klassiteooriatele, poliitilisele sihiteadlikkusele ja agitatsioonile. Samuti on autori kui vaatleja positsioon asendunud läbielaja vaatepunktiga. 
Selle hea näide on Otto Müntheri jutustus „Keldris” ning eriti ülestähendus: „[---] nüüd tundsime seda, mida me sagedasti mitte ei tundnud: Meid rõhuti!" (Münther 1906: 39) Nii tööliskirjanduses kui ka ühiskonnakriitilistes realistlikes teostes esitatakse kontrastset (linna)ruumi, kus ühel pool on jõukas ja rahulolev kesk- või kõrgklass, teisel pool nälgiv ja kurnatud alamkiht; ühel pool uhked mõisad, villad ja salongid, teisel pool vaestemajad ja vabrikud, mis „suitsu ja tolmuga nina kibedaks ja kopsu raskeks teevad" (Eessaare Aadu 1916: 166).

Naturalism on tööliskirjandusega tihedamas seoses, leidub koguni teoseid, mida on keeruline ainult ühte või teise voolu paigutada. Mõlemas kirjandusvoolus on esil virelevad ja vaesunud töölised või talupojad, kelle eluolu iseloomustavad nälg, külm, haigused, ebavõrdsus, kurnav töö, rahulolematus, viha, mässumeelsus ja enneaegne surm. Peamine erinevus on lähtepunktis: naturalismi aluseks on uuenduslik biologism ning erinevad füsioloogia- ja loodusuurimused (Hennoste 2016: 63), tööliskirjandus tõukub XIX sajandi lõpus levima hakanud marksistlikust ja sotsialistlikust ideoloogiast ning sellega kaasnenud ideedest, näiteks kapitalistliku ühiskonna vältimatu üleminek sotsialistlikule ja proletaarse revolutsiooni paratamatus. Usku ülemineku paratamatusesse demonstreerivad näiteks Villem Buki (1913: 15) poeemi „Lina” viimased read: „siin töötav hulk ja vaevamõte / saab jumalikuks ilmajõuks, / kes avab uue ilma ukse / ja rajab tulevikku tee." Samuti kirjutab Lilienbach (1907) luuletuses „Tagasi”: „Edasi! / Võimsatega võideldes, / sõgedaid sõideldes, / uniseid äratades, / kihutades, käratades / edasi!” Eduard Vilde teostes „Raudsed käed” (1898) ja „Lunastus” (1909) on aga esindatud nii naturalistlikud detailirohked kirjeldused töölisklassi elust kui ka „tõus ebateadliku elu sügavusest äratundmispuu viljade poole" (Tuglas 1935: 54) ning proletaarse revolutsiooni kui päästerõnga kujutluspilt. Siiski, just „Lunastuse” kohta on Annika Heinsalu (2015: 12) kirjutanud: „Marksistlik diskursus uuritavas romaanis on oluline, küll aga ei saa tervet teost ainult ühele diskursusele taandada. „Lunastuses” tuleb esile ka teisi mõtlemis-, kõnelemis-, tajumis- ja käitumisviise nagu näiteks darvinism, sotsiaaldarvinism, feminism, kristlus ja teised.” „Raudsete käte” 1954. aasta väljaande järelsõnas on aga pööratud tähelepanu sellele, et proletariaadi klassiteadlikkus ja tööliselu puudutavate küsimustega tegelemine on armastusloo kõrval teisejärgulised, mistõttu ei saa seda ka tööliskirjanduseks nimetada - töölisromaaniks aga küll (Käosaar 1954: 336).

XX sajandi alguse eesti tööliskirjandusele avaldasid mõju ka 1905. ja 1917. aasta revolutsioonid: mässumeelsus, poliitiline õhin ja revolutsiooniromantika põimusid suuremal või vähemal määral tööliskirjanduse peateemadega. Revolutsiooniromantikat kostab näiteks Gustav Tikerpuu (1906) luuletusest „Vabadusvõitleja lootuselaul”: „Seda aega ootan väga, / millal teiste süütutega / vangimaja näen mu ees.” „Vabadusvõitlejateks” olid tõenäoliselt ülestõusnud töölised või talupojad. Mässumeelsus aimub Vassili Möldri kogus „Sõnajalad” luuletuses „Nad räägivad rahust...”: „Meid vaimustab võitlus, sest selles / on elu mõte ning siht” (Proletarlane 1910: 85). Luuletus kätkeb tööliskirjandusele omast meie-nende vastandust ning selle lópuread täheldavad, et töliste päralt on tulevik. Märkimisväärne on ka tekstide järjekord Möldri kogus: siin tsiteeritud luuletusele eelneb sellega ideeliselt haakuv „Kodanlaste hümnus” (Proletarlane 1910: 83-84), mõlemas väljendub vastumeelsus 
kodanliku klassi suhtes, tööliste ja kodanlaste vastandamine. Tööliskirjanduses oli revolutsiooniromantika olulisel kohal ka seetõttu, et just revolutsiooniga pidi langema senine kapitalistlik kord (Jennings 2003: 11) ning siinmail ka tsaarivalitsus. Tollased ühiskondlikud murrangud ja meeleolud mõjutasid teisigi XX sajandi alguse Eesti kirjandusvoole (uusromantismi, sümbolismi jm). Adson (1948: 76) on kogu XX sajandi alguse eesti kirjanduse teemadest muu hulgas rõhutanud kaastunde avaldamist revolutsionääridele „nende põgenemistel, vangilangemistel ja sunnitööle saatmisel”. Õigupoolest leidus revolutsiooni motiive ja sümboleid ka „Noor-Eesti” I albumis (1905), mille diskursusele toonased tööliskirjanikud ise end aktiivselt vastandasid (nt Lilienbach 1910a; Pöögelmann 1933: 92-93; vt ka Gailit 1911).

Sotsialistlik realism jõudis Reet Neithali (1999: 142) sõnul Eestisse 1932. aasta paiku. Selles on esiplaanil juhtide ja kommunistliku partei diktatuuri ülistamine (Neithal 1999: 142), mida varasest eesti tööliskirjandusest pigem ei leia. Jaan Undusk (2013: 41, 45) selgitab, et sotsialistlik realism oli ühtlasi geograafiliselt, st Nõukogude Liidu piiriga määratletud stiil (tööliskirjandust viljeleti aga ka väljaspool Nõukogude Liitu), mille järgimine pärssis kirjanike ja kunstnike eneseväljendust, muutes selle kohati ilutsevaks ja lipitsevaks. Tööliskirjandusest on sotsialistlikku realismi kandunud siiski mitu tunnust, näiteks sotsialistlik vaatenurk ja töölisklassi õigustamine. Nõukogude Eesti perioodil aga sotsialistliku realismi ja eesti proletaarse kirjanduse vahel piir hägustus, seega leidub kahel kirjandusvoolul omajagu sarnasusi: kehtiva ühiskonnakorra, juhtide ja partei diktatuuri ülistamine, positiivne kangelane ja tema poliitiline teadlikkus, konkreetse majanduseesmärgi täitmine jm. Omaette vaatlemist vääriks 1920.-1930. aastatel Nõukogude Liidus kirjutatud eesti tööliskirjanike looming ning eriti nende teoste suhe varase sotsialistliku realismiga.

Just sellepärast, et paljudest tööliskirjanduse teostest leiab ka mõne teise kirjandusvoolu, olgu siis kriitilise realismi, sotsialistliku realismi, naturalismi või revolutsioonikirjanduse jälgi, muutub tööliskirjanduse mõiste määratlemine ja selgepiiriliste näidete toomine keerulisemaks. Juhan Lilienbachi (1910c) luuletuses „Tasakaal”, mille esimene stroof kõlab nõnda: „Nähke vaeva, tehke tööd / päevad otsa, läbi ööd, / sest et juba laisklejad / kallist aega raiskavad", võib näha märke nii kriitilisest realismist (kriitilist suhtumist kõrgklassi märgib „laisklejad / kallist aega raiskavad”), naturalismist (töölisklassi töötundidele viitab värss „päevad otsa, läbi ööd”), tööliskirjandusest (laisklejate ja mittelaisklejate vastandus tähendab ühtlasi meie-nende jaotust) ja revolutsioonikirjandusest (kõlama jääb üleskutse võitlusele nii „laisklejate" kui ka ületöötamise vastu).

\section{Kokkuvõte}

Tööliskirjanduse mõistet ja töölisklassi kujutava kirjanduse ajalugu iseloomustab määratluste ja nende kummutamiste rohkus, mida on mõjutanud poliitilised, ajaloolised, rahvuslikud ja ideoloogilised aspektid. Sellest lähtuvalt pole senini leitud ühtset ja heaks kiidetud tööliskirjanduse definitsiooni. Konkreetne definitsioon puudub ka eesti tööliskirjandusel, senini on seda piiritletud tunnusjoonte kaudu. 
Tööliskirjaniku määratlemisel võiks lähtuda nii autori poliitilistest seisukohtadest, eneseteadvusest kui ka loomingu teemadest. Töölistemaatikat kajastavaid tekste kirjutasid XX sajandi alguses poliitikud (nt Hans Pöögelmann, Jaan Anvelt), koolmeistrid (nt Otto Münther), ajakirjandusväljaannete toimetajad (nt Juhan Lilienbach), aga ka lihttöölised (nt Gustav Tikerpuu), kes tihti olid küll tundmatud ja kasutasid pseudonüüme, nagu Vabrikuneiu, Vabrikutööline jm. Teemad lähtusid paljuski autori tegevusvaldkonnast. Eesti tööliskirjandust iseloomustab irooniline ja kriitiline suhtumine nii tsaarivalitsusse, baltisaksa mõisnikesse kui ka üldiselt töölisliikumise vastastesse. Samuti on omapärased külaühiskonna probleemsituatsioonide esitamine ja rahvuslike eripärade tähtsustamine.

\section{KIRJANDUS}

Adson, Artur 1948. Ise Idas - silmad Läänes. Mälestusi 1905. a. revolutsiooni ja esimese maailmasõja vaheaastaist. Vadstena: Orto.

Andresen, Nigol 1959. Eessaare Aadu vastuvõtt omaaegses arvustuses. - Keel ja Kirjandus, nr 11, lk 647-653.

Annus, Epp; Epner, Luule; Järv, Ants; Olesk, Sirje; Süvalep, Ele; Velsker, Mart 2001. Eesti kirjanduslugu. Tallinn: Koolibri.

Buk, Villem 1913. Lina. Narva: Kõne.

Clark, Katerina 2017. Working-class literature and/or proletarian literature: Polemics of the Russian and Soviet literary left. - Working-Class Literature(s): Historical and International Perspectives. Toim John Lennon, Magnus Nilsson. Stockholm: Stockholm University Press, lk 1-30.

Clarke, Ben; Hubble, Nick 2018. Introduction. - Working-Class Writing. Theory and Practice. Toim B. Clarke, N. Hubble. London: Palgrave Macmillan, lk 1-14.

Depman, Johan 1961. Juhan Lilienbachi ühe luuletuse saatusest. - Keel ja Kirjandus, nr 9, lk 537.

Eessaare, Aadu 1916. Räästaalused. Tallinn: Mõte.

Elbe, J. 1909. Sellesama küsimuse kohta. - Mõtted I. Toim Juhan Lilienbach. Tallinn: Mõte, lk 113-127.

Ertis, Eduard 1967. Eesti Proletaarsete Kirjanikkude Assotsiatsioon Leningradis. - Keel ja Kirjandus, nr 7, lk 385-396.

Gailit, August 1911. Klassivahed ja „Noor-Eesti” kunst. - Mõtted II. Toim Juhan Lilienbach. Tallinn: J. Lilienbach, lk 89-113.

Hasselblatt, Cornelius 2016. Eesti kirjanduse ajalugu. Tlk Mari Tarvas, Maris Saagpakk, Ave Mattheus. (Heuremata. Humanitaarteaduslikke monograafiaid.) Tartu: Tartu Ülikooli Kirjastus.

Heinsalu, Annika 2015. Eduard Vilde „Lunastus” modernsuse kontekstis. Magistritöö. Tallinna Ülikool. [ETERA.]

Hennoste, Tiit 2016. Eesti kirjanduslik avangard. 20. sajandi algul. Hüpped modernismi poole I. (Heuremata. Humanitaarteaduslikke monograafiaid.) Tallinn-Tartu: Tartu Ülikooli Kirjastus. 
Hyttinen, Elsi; Launis, Kati 2017. Writing of a different class? The first 120 years of workingclass fiction in Finland. - Working-Class Literature(s): Historical and International Perspectives. Toim John Lennon, Magnus Nilsson. Stockholm: Stockholm University Press, lk 65-94.

Jaakson, Elvi 1955. Eesti proletaarse kirjanduse rajaja. - Nõukogude Õpetaja 29. X, lk 3-4.

Jennings, Jeremy 2003. Socialism: an introduction. - Socialism. Critical Concepts in Political Science. Koost J. Jennings. New York: Routledge, lk 1-23.

Jänes, Harri; Meiesaar, August; Sööt, Bernard 1938. Eesti kirjanduslugu II. Tartu: Eesti Kirjastuse Kooperatiiv.

Kahu, Meelik 1967. Eesti töölispäevalehe arenguteelt. - Keel ja Kirjandus, nr 11, lk 670-679.

Kalda, Mart [= Heino Puhvel] 1958. Tähelepanuväärne uusväljaanne. - Keel ja Kirjandus, nr $1, \mathrm{lk} 45-47$.

Karjahärm, Toomas 2013. 1905. aasta Eestis. Massiliikumine ja vägivald maal. Tallinn: Argo.

Karjahärm, Toomas; Pullat, Raimo 1975. Eesti revolutsioonitules 1905-1907. Tallinn: Eesti Raamat.

Klaus, Gustav H. 1985. Literature of Labour. 200 Years of Working-Class Writing. New York: St. Martin's Press.

Klaus, Hegely 2019. Eesti töölisluule 20. sajandi alguses töölisalbumite põhjal. Magistritöö. Tartu Ülikool. [Dspace.]

Korsakas, Kostas; Doveika, Kostas; Galinis, Vytautas; Kubilius, Vytautas; Lankutis, Jonas; Pranskus, Bronius; Vanagas, Vytautas; Žèkaite, Janina 1965. Lietuvių literatūros istorija III. Kapitalizmo epocha (1917-1940). Vilnius: Mintis.

Kreek, Jaan 1905. Aga õues tähed paistvad... - Edasi I. Toim Juhan Lilienbach. Tallinn: J. Lilienbach, lk 17.

Kuuli, Olaf 1999. Sotsialistid ja kommunistid Eestis 1917-1991. Tallinn: Olaf Kuuli kirjastus.

Käosaar, Juhan 1954. Ajalooline taust. - Eduard Vilde, Teosed. Külmale maale. Raudsed käed. Tallinn: Eesti Riiklik Kirjastus, lk 319-338.

Kärner, Jaan 1921. Aja laulud. Tallinn: Varrak.

Laitinen, Kai 1991. Suomen kirjallisuuden historia. Helsinki: Otava.

Laitinen, Kai; Laurila, Aarne; Niemi, Irmeli; Sarajas, Annamari; Warburton, Thomas 1965. Suomen kirjallisuus V. Joel Lehtosesta Antti Hyryyn. Toim A. Sarajas. Keuruu: Kustannusosakeyhtiö Otava.

Laul, Endel 1955. Eesti 1905.-1907. a. revolutsioonilis-satiirilise ajakirjanduse ajaloost. - Sirp ja Vasar 6. V, lk 3-4.

Launis, Kati 2015. The making of the finnish working class in early twentieth-century working-class literature. - Journal of Finnish Studies, nr 2, lk 14-34.

Lennon, John; Nilsson, Magnus 2017. Introduction. - Working-Class Literature(s): Historical and International Perspectives. Toim J. Lennon, M. Nilsson. Stockholm: Stockholm University Press, lk 9-18.

Lilienbach, Juhan 1905. Üksainus soov. - Edasi I. Toim J. Lilienbach. Tallinn: J. Lilienbach, $1 \mathrm{k} 91$.

Lilienbach, Juhan 1907. Tagasi. - Tagasi. Toim J. Lilienbach. Tallinn, lk 3.

Lilienbach, Juhan 1910a. „Kunstnikule”. - Edasi III. Jõuluks. Toim J. Lilienbach. Tallinn: J. Lilienbach, lk 68. 
Lilienbach, Juhan 1910b. Lambatall. - Edasi III. Jõuluks. Toim J. Lilienbach. Tallinn: J. Lilienbach, lk 26.

Lilienbach, Juhan 1910c. Tasakaal. - Edasi III. Jõuluks. Toim J. Lilienbach. Tallinn: J. Lilienbach, lk 68.

Linde, Bernhard 1911. Kirjandusline ülevaade. - Eesti Kirjandus, nr 9, lk 343-352.

Markels, Julian 2003. The Marxian Imagination: Representing Class in Literature. New York: Monthly Review Press.

Meisel, Peeter [= Peeter Kõvamees] 1932. Viis aastat võitlust eesti proletaarse kirjanduse eest. - Rahvusdemokratismi vastu. Kriitilised artiklid. Koost P. Meisel, Karl Trein. Leningrad: Külvaja, lk 6-27.

Münther, Otto 1906. Sulejoonistused. Tartu: K. Sööt.

Münther, Otto 1914/1915. Eesti noorematest kirjanikkudest. - Edasi VIII. Toim Juhan Lilienbach. Tallinn: G. Kalla trükk, lk 3-8.

Neithal, Reet 1999. Mis on mis kirjanduses. Kirjandusterminite leksikon keskkoolile. Tallinn: Koolibri.

Nilsson, Magnus 2017. The making of Swedish working-class literature. - Working-Class Literature(s): Historical and International Perspectives. Toim John Lennon, M. Nilsson. Stockholm: Stockholm University Press, lk 95-127.

Nilsson, Magnus; Lennon, John 2016. Defining working-class literature(s): A comparative approach between U.S. working-class studies and Swedish literary history. - New Proposals: Journal of Marxism and Interdisciplinary Inquiry, kd 8, nr 2, lk 39-61.

Palmgren, Raoul 1965. Työläiskirjallisuus. (Proletaarikirjallisuus.) Käsite- ja aatehistoriallinen käsiteselvittely. Helsinki: WSOY.

Perera, Sonali 2014. No Country: Working-Class Writing in the Age of Globalization. New York: Columbia University Press.

Pilv, Aare 2015. Eesti varamarksistlikust koidust punapagulaste tragöödiani. - Vikerkaar, nr 7-8, lk 50-55.

Proletarlane, V. [= Vassili Mölder] 1910. Sõnajalad. V. Proletarlase luuletused. Tallinn: Mõte.

Puhvel, Heino 1969. Eesti kirjanduse ajalugu III. XIX sajandi lõpust 1917. aastani. Tallinn: Eesti Raamat.

Pöögelmann, Hans 1907. Kunst ja klassivõitlus. - Sõnumed 31. III, lk 1.

Pöögelmann, Hans 1933. Kirjanduslikult rindelt. Leningrad: Külvaja.

Rancière, Jacques 2012. Proletarian Nights: The Workers' Dream in Nineteenth-Century France. London: Verso.

Russo, John; Linkon, Sherry Lee 2005. New Working-Class Studies. Oxford: IRL Press.

Sabolev, Olga 2017. The symbol of the symbolists. Aleksandr Blok in the changing Russian literary canon. - Twentieth-Century Russian Poetry. Reinventing the Canon. Toim Katharine Hodgson, Joanne Shelton, Alexandra Smith. Cambridge: Open Book Publishers, lk 123-155.

Sikemäe, Ilmar; Lepik, Harald (koost) 1951. Eesti proletaarne kirjandus. Valimik jutustusi ja luuletusi. Tallinn: Eesti Riiklik Kirjastus.

Suits, Gustav; Lepik, Mart 1932. Eesti kirjandusajalugu tekstides I. Tartu: Akadeemiline Kirjandusühing.

Tikerpuu, Gustav 1906. Vabadusvõitleja lootuselaul. - Tiiu Tasane, nr 3, lk 5. 
Tuglas, Friedebert 1935. Eduard Vilde: Lunastus (1909). - F. Tuglas, Kriitika. IV. Tartu: NoorEesti, lk 52-60.

Tuglas, Friedebert 1947. Eesti kirjanduse ajalugu IV. Kriitiline realism. Tartu: Teaduslik Kirjandus.

Tööliste hinge-elust 1910. - Tallinna Teataja 17. V, nr 75, lk 1.

Undusk, Jaan 2013. Sotsialistliku realismi lendav reaalsus. Esteetika kui reaalpoliitika riist. Vikerkaar, nr 6, lk 39-61.

Vibulane, Kosto 1909. Vabrikus. - Mõtted I. Toim Juhan Lilienbach. Tallinn: Mõte, lk 209.

Vibulane, Kosto 1910a. Ju olen kuulnud... - Edasi III. Jõuluks 1910. Toim Juhan Lilienbach. Tallinn: J. Lilienbach, lk 15.

Vibulane, Kosto 1910b. Lahkumine. - Edasi III. Jõuluks 1910. Toim Juhan Lilienbach. Tallinn: J. Lilienbach, lk 46.

Hegely Klaus (snd 1995), MA, Eesti Teaduste Akadeemia Underi ja Tuglase Kirjanduskeskuse muuseumiosakonna peavarahoidja (Väikese Illimari 12, 11623 Tallinn), hegely@utkk.ee

\section{The outlines and features of early Estonian working-class literature}

Keywords: working-class literature, literary history, working-class movement

The article is motivated by the marginal position of working-class literature in modern academic literary studies and the available theoretical views and definitions of working-class literature, which are largely obsolete or just superficial. The article highlights the problems associated with defining the concept of working-class literature, based on the relevant theories of well-recognised researchers such as John Lennon, Magnus Nilsson, Raoul Palmgren, Elsi Hyttinen and others. The focus is on the main definitions of working-class literature so far and their critique. The article seeks to provide answers to questions concerning the definition of working-class literature, its spread, research and main features. A polemic discussion is also presented about the definition of a workers' writer. In addition, the text examines the relationship between working-class literature and other realistic literary currents prevalent in the late $19^{\text {th }}$ and early $20^{\text {th }}$ century, and outlines its spread and research specifically in Estonia. The final part of the article summarises the specific traits of Estonian working-class literature from the early $20^{\text {th }}$ century, including traces of the relationship between Estonians and Baltic Germans, the Estonians' agrarian point of view, the revolutions of 1905 and 1917, etc. The article is a follow-up of a Master's thesis on Estonian working-class poetry, defended in the spring of 2019.

Hegely Klaus (b. 1995), MA, Head Treasurer of the Museum Department at Under and Tuglas Literary Centre, Estonian Academy of Sciences (Väikese Illimari 12, 11623 Tallinn), hegely@utkk.ee 